\section{Identification of Foliar Salt Tolerance of Woody Perennials Using Chlorophyll Fluorescence}

\author{
G.C. Percival ${ }^{1}$ \\ R.A. Bartlett Tree Research Laboratory, 2 Early Gate, Whiteknights, University \\ of Reading, Reading, RG6 6AU, U.K.
}

Additional index words. shrubs, trees, salt damage, salinity, urban landscapes, environmental stress, laboratory method

\begin{abstract}
Aims of this investigation were to determine whether chlorophyll fluorescence values obtained from excised leaves of woody perennials subjected to salinity stress under laboratory conditions provided a measurable indicator of whole plant salinity tolerance. Laboratory tests consisted of measurements of the ratio of variable to maximal chlorophyll fluorescence $\left(F_{v} / F_{m}\right)$ performed on excised leaves taken from thirty woody perennials following immersion in salt solutions ranging from concentrations of $2 \%$ to $7 \%$. Based on reductions in $F_{v} / F_{m}$ of excised leaves following salinity treatments plants were ranked in order of tolerance. Whole plants of six of the thirty species tested were then subjected to a foliar applied salt at a concentration of $7 \%$ and placed under glass for 14 weeks. Damage to, and recovery of whole plants from salt damage as measured by chlorophyll fluorescence, leaf necrosis and chlorophyll content mirrored tolerance ranking of excised leaves under laboratory conditions. In addition, based on reductions in plant growth at the cessation of the experiment, salt tolerance followed a similar order as that obtained from $F_{v} / F_{m}$ values of excised leaves. Results indicate that testing of excised leaf material of woody perennials under laboratory conditions using chlorophyll fluorescence offers a potentially quick, reliable and inexpensive procedure that can provide a useful means of estimating whole plant salt tolerance.
\end{abstract}

Woody perennials such as trees and shrubs, planted within towns and cities provide important practical (absorption of air and car-exhaust pollutants), ecological, and psychological benefits (Harris, 1998). Plant deaths due to excess salinity as a result of deicing salt applications are a major problem in urban landscapes. Symptoms of salt toxicity include crown dieback, lesions on the stem or trunk, and leaf scorch. With time, symptoms may accumulate causing tip burn of conifer, necrosis of needles, die back of limbs and tree death (Dobson, 1991). Such losses can be a heavy financial burden to local authorities. Consequently, identification and use of salt tolerant species will become of greater importance as future resource allocations to urban tree management are likely to decline, increasing pressure to deliver services at fewer costs (Percival and Hitchmough, 1995). As woody perennials planted in streets, public recreation areas and car parks are selected primarily on their aesthetic qualities (flowers, bark, berries, leafcolor), little information exists with regard to their foliar salt tolerance.

Chlorophyll fluorescence has proved particularly useful in salinity tolerance evaluation programmes as 1) the effects of salt damage can be detected before visible signs of deterioration and 2) a quantitative assessment to rank plant species depending on their salt sensitivity is provided (Jimenez, 1997; Percival and Fraser,

Received for publication 2 Feb. 2004. Accepted for publication 17 May 2005. The author is grateful for funding from the Stanley Smith (U.K.) Horticultural Trust and the International Society of Arboriculture TREE FUND (John Z Duling grant program).

'E-mail gpercival@bartlettuk.com. altered Photosystem II (PSII) activity, caused

NSNonsignificant. directly or indirectly by stress applied to the leaf tissue as a measure of damage to the thylakoid membrane (Brennan and Jefferies, 1990). The practical advantages of using chlorophyll fluorescence include the fact that fluorescence measurements use a light portable piece of equipment, measurements are non-destructive and non-invasive and readings are obtained in $<1$ second allowing for many plants to be evaluated in a single day. Evidence also exists that alterations in chlorophyll fluorescence values from excised leaves subject to environmental stress such as chilling, heat and salinity under laboratory conditions offers a system to identify and evaluate stress tolerance with which to rank whole plants (Brennan and Jefferies, 1990; Greaves and Wilson, 1987; Hakam et al., 2000; Percival and Henderson 2003; Yamada et al., 1996).

Objectives of this investigation were to determine whether chlorophyll fluorescence values obtained from excised leaves of woody perennials subject to salt stress under laboratory conditions could be used to provide a measurable indicator of whole plant salinity tolerance and thereby provide information as to their usefulness for urban plantings in areas subject to airborne salt particles such as coastal regions and roadside verges.

\section{Materials and Methods}

Plant material. The experiment used four year old stock of 30 woody perennials commonly used in U.K. plantings schemes (Table 1) obtained from a range of commercial sup-

Table 1. The effect of leaf detachment on $\left(\mathrm{F}_{\mathrm{v}} / \mathrm{F}_{\mathrm{m}}\right)$ of woody plants tested after $72 \mathrm{~h}$ dark storage at $18^{\circ} \mathrm{C}$. All values mean of 60 leaves ( 12 plants, 5 leaves per plant).

\begin{tabular}{|c|c|c|}
\hline \multirow[b]{2}{*}{ Species } & \multicolumn{2}{|c|}{$\mathrm{F}_{\mathrm{v}} / \mathrm{F}_{\mathrm{m}}$} \\
\hline & Whole plant & Detached leaf \\
\hline Brachyglottis dunedin hybrid 'Sunshine' & 0.811 & $0.803^{\mathrm{NS}}$ \\
\hline Euоnymus fortunei ‘Silver Queen' & 0.822 & $0.813^{\mathrm{NS}}$ \\
\hline Ribes odoratum & 0.805 & $0.820^{\mathrm{NS}}$ \\
\hline Euonymus fortunei 'Emerald \& Gold' & 0.831 & $0.830^{\mathrm{NS}}$ \\
\hline Laburnum anagyroides & 0.809 & $0.811^{\mathrm{NS}}$ \\
\hline Spirea japonica 'Allgold' & 0.820 & $0.817^{\mathrm{NS}}$ \\
\hline Cotoneaster cashmiriensis & 0.809 & $0.800^{\mathrm{NS}}$ \\
\hline Hedera helix 'Hispanica' & 0.822 & $0.824^{\mathrm{NS}}$ \\
\hline Rosa rugosa var. alba & 0.810 & $0.819^{\mathrm{NS}}$ \\
\hline Hypericum lancasteri & 0.800 & $0.816^{\mathrm{NS}}$ \\
\hline Berberis $\times$ carminea 'Buccaneer' & 0.808 & $0.816^{\mathrm{NS}}$ \\
\hline Berberis thunbergii 'Aurea' & 0.789 & $0.811^{\mathrm{NS}}$ \\
\hline Hebe brachysiphon 'White Gem' & 0.821 & $0.807^{\mathrm{NS}}$ \\
\hline Ribes sanguineum & 0.799 & $0.800^{\mathrm{NS}}$ \\
\hline Potentilla fruitcosa 'Abbotswood' & 0.808 & $0.827^{\mathrm{NS}}$ \\
\hline Crataegus monogyna & 0.818 & $0.818^{\mathrm{NS}}$ \\
\hline Pieris ‘Forest Flame’ & 0.822 & $0.805^{\mathrm{NS}}$ \\
\hline Berberis thunbergii f. atropurpurea & 0.809 & $0.812^{\mathrm{NS}}$ \\
\hline Daphne mezereum & 0.820 & $0.803^{\mathrm{NS}}$ \\
\hline Mahonia aquifolium & 0.834 & $0.830^{\mathrm{NS}}$ \\
\hline Buddleja davidii & 0.800 & $0.811^{\mathrm{NS}}$ \\
\hline Pyrancantha 'Orange Glow' & 0.819 & $0.802^{\mathrm{NS}}$ \\
\hline Hedera helix 'Golden Child' & 0.823 & $0.824^{\mathrm{NS}}$ \\
\hline Cotoneaster lacteus & 0.817 & $0.814^{\mathrm{NS}}$ \\
\hline Viburnum tinus & 0.803 & $0.807^{\mathrm{NS}}$ \\
\hline Sorbus aria & 0.821 & $0.810^{\mathrm{NS}}$ \\
\hline Forsythia $\times$ intermedia & 0.830 & $0.819^{\mathrm{NS}}$ \\
\hline Cornus alba 'Elegantissima' & 0.810 & $0.820^{\mathrm{NS}}$ \\
\hline Weigela florida 'Variegata' & 0.829 & $0.827^{\mathrm{NS}}$ \\
\hline Viburnum $\times$ carlcephalum & 0.825 & $0.826^{\mathrm{NS}}$ \\
\hline LSD $p<0.05$ & & \\
\hline LSD $p<0.01$ & & \\
\hline
\end{tabular}


Table 2. Regressions of $\mathrm{F} / \mathrm{F}_{\mathrm{m}}$ values with increasing salt $(\mathrm{NaCl})$ exposure in foliar tissue of thirty woody perennials (standard errors and the estimated regression coefficients are given in parentheses); $y=$ chlorophyll fluorescence value; $a=$ chlorophyll fluorescence of control value (calculated intercept); $b$ $=$ rate of fluorescence decrease with increasing salt concentration $(\mathrm{T})$. All values mean of 60 leaves $(12$ plants, 5 leaves per plant). Species are ranked in order of tolerance based on reductions in $\mathrm{F}_{\mathrm{v}} / \mathrm{F}_{\mathrm{m}}$.

\begin{tabular}{|c|c|}
\hline Species & Regression: $y=\mathrm{a}+\mathrm{bT}$ \\
\hline Brachyglottis dunedin hybrid 'Sunshine' & $\mathrm{y}=0.82+0.003 \mathrm{~T}(0.06)(0.002)$ \\
\hline Euonymus fortunei 'Silver Queen’ & $\mathrm{y}=0.83+0.002 \mathrm{~T}(0.03)(0.001)$ \\
\hline Ribes odoratum & $\mathrm{y}=0.83-0.001 \mathrm{~T}(0.04)(0.001)$ \\
\hline Euonymus fortunei 'Emerald \& Gold' & $\mathrm{y}=0.83-0.015 \mathrm{~T}(0.04)(0.013)$ \\
\hline Laburnum anagyroides & $\mathrm{y}=0.80-0.002 \mathrm{~T}(0.03)(0.002)$ \\
\hline Spirea japonica 'Allgold' & $\mathrm{y}=0.81-0.003 \mathrm{~T}(0.04)(0.010)$ \\
\hline Cotoneaster cashmiriensis & $\mathrm{y}=0.82-0.003 \mathrm{~T}(0.07)(0.003)$ \\
\hline Hedera helix Hispanica & $\mathrm{y}=0.83-0.004 \mathrm{~T}(0.06)(0.002)$ \\
\hline Rosa rugosa var. alba & $\mathrm{y}=0.82-0.004 \mathrm{~T}(0.03)(0.003)$ \\
\hline Hypericum lancasteri & $\mathrm{y}=0.81-0.007 \mathrm{~T}(0.04)(0.010)$ \\
\hline Berberis $\times$ carminea 'Buccaneer' & $\mathrm{y}=0.80-0.008 \mathrm{~T}(0.05)(0.004)$ \\
\hline Berberis thunbergii 'Aurea' & $\mathrm{y}=0.75-0.008 \mathrm{~T}(0.02)(0.009)$ \\
\hline Hebe brachysiphon 'White Gem' & $\mathrm{y}=0.82-0.009 \mathrm{~T}(0.07)(0.007)$ \\
\hline Ribes sanguineum & $\mathrm{y}=0.79-0.009 \mathrm{~T}(0.02)(0.010)$ \\
\hline Potentilla fruitcosa 'Abbotswood' & $\mathrm{y}=0.81-0.010 \mathrm{~T}(0.02)(0.009)$ \\
\hline Crataegus monogyna & $\mathrm{y}=0.84-0.011 \mathrm{~T}(0.03)(0.008)$ \\
\hline Pieris 'Forest Flame' & $\mathrm{y}=0.81-0.012 \mathrm{~T}(0.03)(0.011)$ \\
\hline Berberis thunbergii f. atropurpurea & $\mathrm{y}=0.80-0.013 \mathrm{~T}(0.04)(0.007)$ \\
\hline Daphne mezereum & $\mathrm{y}=0.82-0.013 \mathrm{~T}(0.03)(0.010)$ \\
\hline Mahonia aquifolium & $\mathrm{y}=0.83-0.017 \mathrm{~T}(0.05)(0.007)$ \\
\hline Buddleja davidii & $\mathrm{y}=0.79-0.020 \mathrm{~T}(0.04)(0.017)$ \\
\hline Pyrancantha 'Orange Glow' & $\mathrm{y}=0.82-0.020 \mathrm{~T}(0.02)(0.013)$ \\
\hline Hedera helix 'Golden Child' & $\mathrm{y}=0.81-0.020 \mathrm{~T}(0.05)(0.022)$ \\
\hline Cotoneaster lacteus & $\mathrm{y}=0.83-0.025 \mathrm{~T}(0.05)(0.018)$ \\
\hline Viburnum tinus & $\mathrm{y}=0.83-0.027 \mathrm{~T}(0.04)(0.013)$ \\
\hline Sorbus aria & $\mathrm{y}=0.81-0.031 \mathrm{~T}(0.05)(0.021)$ \\
\hline Forsythia $\times$ intermedia & $\mathrm{y}=0.83-0.033 \mathrm{~T}(0.04)(0.024)$ \\
\hline Cornus alba 'Elegantissima' & $\mathrm{y}=0.81-0.038 \mathrm{~T}(0.03)(0.044)$ \\
\hline Weigela florida 'Variegata' & $\mathrm{y}=0.83-0.041 \mathrm{~T}(0.05)(0.026)$ \\
\hline Viburnum $\times$ carlcephalum & $\mathrm{y}=0.82-0.056 \mathrm{~T}(0.02)(0.077)$ \\
\hline
\end{tabular}

pliers. Upon arrival plants remained outdoors subject to natural environmental conditions and watered as required. In early April all plants were moved to a polythene tunnel to protect against possible spring frosts. Salt treatments commenced in early May when all species were in full leaf. To keep the physiological age of the leaves comparable throughout the experiment only fully expanded 28- to 31-dold leaves were excised from whole plants and subject to salinity stress under laboratory conditions; well beyond the initial $21 \mathrm{~d}$ required after leaf flush (about early April), to allow the photosynthetic apparatus to fully develop (Cannell et al., 1983; Kitao et al., 1998). Likewise following foliar application of salt to whole plants, measurements of chlorophyll fluorescence, leaf necrosis and chlorophyll content were made only on fully expanded 28- to 31-d-old leaves. Leaves were tagged in whole-plant studies to ensure only the same leaf was measured repeatedly.

Salt treatments: Excised leaves under laboratory conditions. Five fully expanded leaves per species were excised from whole plants. Immediately following detachment, leaves were immersed in a $0 \%$ (control) $1 \%$,
$3 \%, 5 \%$, or $7 \%$ salt $(\mathrm{NaCl})$ solution for $2 \mathrm{~min}$ to represent mild, standard and severe salt exposure within the U.K. (Dobson, 1991). face down, in a petri dish on moist Watmans filter paper sealed with a thin polythene film permeable to air but not water and placed in a Merck environmental growth chamber at $18{ }^{\circ} \mathrm{C}$ for $72 \mathrm{~h}$ in darkness. All material was prepared within $2 \mathrm{~h}$ of collection.

The effect of leaf detachment alone on chlorophyll fluoresce values was monitored with time by comparing excised leaf values not subject to salt damage against values from whole plants every $24 \mathrm{~h}$. In all cases values from excised leaves did not significantly differ from whole plants until day 6 (data not shown). Consequently, leaves were assessed after 72 $\mathrm{h}$ following salt immersion, a time by which detrimental effects on chlorophyll fluorescence values could be detected.

Salt treatments: Whole plants. Salinity treatments consisted of foliar applications of a $7 \%$ salt solution $(\mathrm{NaCl})$ applied via a hand held spray applicator until runoff. Immediately following salt application plants were placed in a heated glasshouse and leaf chlorophyll Afterwhich leaves were placed, abaxial sur- fluorescence, necrosis and chlorophyll content values recorded at weekly intervals until week 6 and every 2 weeks thereafter until week 14 . Growing conditions under glass were $22 \pm 2$ ${ }^{\circ} \mathrm{C}$ supplemented with 400 -W high-pressure sodium lamps (SON/T) providing a photoperiod of $16 \mathrm{~h} \mathrm{light} / 8 \mathrm{~h}$ dark and minimum 250 $\mu \mathrm{mol} \cdot \mathrm{m}^{-2} \cdot \mathrm{s}^{-1}$ Photosynthetically Active Radiation (PAR) at the tree crown. The experimental design used was completely randomised and plants were rerandomised on a two weekly basis. Experiments were undertaken in May 2001 and 2003 using six plants per treatment. Where abscission or mortality of tagged leaves occurred the nearest adjacent leaf was tagged for future measurements. Only leaves present at the time of salt application were measured throughout this investigation to record regeneration of the leaf photosynthetic apparatus post salt treatment. Although new leaf formation was observed in all species between weeks 6 to 7 no measurements of newly formed leaf tissue were made. Controls consisted of trees sprayed with distilled water and kept under glasshouse conditions to permit quantification of reductions in growth at the cessation of the experiment.

Chlorophyllfluorescence. At each sampling date leaves were adapted to darkness for 30 min by attaching light exclusion clips to the leaf surface and chlorophyll fluorescence was measured using a HandyPEA portable fluorescence spectrometer (Hansatech Instruments Ltd., King's Lynn, U.K.). Measurements were recorded up to $1 \mathrm{~s}$ with a data acquisition rate of $10 \mu \mathrm{s}$ for the first $2 \mathrm{~ms}$ and of $1 \mathrm{~ms}$ thereafter. The fluorescence responses were induced by a red (peak at $650 \mathrm{~nm}$ ) light of $1500 \mu \mathrm{mol} \cdot \mathrm{m}^{-2} \cdot \mathrm{s}^{-1}$ PAR intensity provided by an array of six light-emitting diodes. The ratio of variable $\left(\mathrm{F}_{\mathrm{v}}=\mathrm{F}_{\mathrm{m}}-\mathrm{F}_{\mathrm{o}}\right)$ to maximal $\left(\mathrm{F}_{\mathrm{m}}\right)$ fluorescence, i.e., $F_{v} / F_{m}$ where $F_{o}=$ minimal fluorescence, of dark adapted leaves was used to quantify the detrimental effects of salt on leaf tissue. $\mathrm{F}_{\mathrm{v}} / \mathrm{F}_{\mathrm{m}}$ is considered a quantitative measure of the maximal or potential photochemical efficiency or optimal quantum yield of photosystem II (Willits and Peet, 2001). Likewise $\mathrm{F}_{\mathrm{v}} / \mathrm{F}_{\mathrm{m}}$ values are the most popular index used as a measure of plant vitality and early diagnostic of stress (Meinander et al., 1996)

Chlorophyll analysis. AMinolta SPAD-502 chlorophyll meter was used. Chlorophyll was measured at the mid point of the leaf next to the main leaf vein. Calibration was obtained by measurement of absorbance at 663 and $645 \mathrm{~nm}$ in a spectrophotometer (PU8800 Pye Unicam) after extraction with $80 \% \mathrm{v} / \mathrm{v}$ aqueous acetone (regression equation: $5.80+0.057 \mathrm{x}$; $r^{2}$ adj $\left.=0.82, P \leq 0.01\right)$ (Lichtenthaler and Wellburn, 1983).

Table 3. $P$ values for growth and tree vitality of six woody perennials (Brachyglottis dunedin hybrid 'Sunshine', Cotoneaster cashmiriensis, Ribes sanguineum, Pyrancantha 'Orange Glow', Forsythia $\times$ intermedia, Viburnum $\times$ carlcephalum) following salt treatments. $P<0.05$ are considered significant

\begin{tabular}{|c|c|c|c|c|c|c|c|c|c|c|}
\hline Factor & $\mathrm{Ht}$ & $\begin{array}{l}\text { Leaf } \\
\text { area }\end{array}$ & $\begin{array}{l}\text { Leaf } \\
\text { size }\end{array}$ & $\begin{array}{c}\text { Shoot } \\
\text { and } \\
\text { leaf } \\
\text { dry wt }\end{array}$ & $\begin{array}{l}\text { Root } \\
\text { dry wt }\end{array}$ & $\begin{array}{l}\text { Root } \\
\text { to } \\
\text { shoot } \\
\text { ratio }\end{array}$ & $\begin{array}{c}\text { Total } \\
\text { plant } \\
\text { dry wt }\end{array}$ & $\mathrm{F}_{\mathrm{v}} / \mathrm{F}_{\mathrm{m}}$ & $\begin{array}{c}\text { Leaf } \\
\text { necrosis }\end{array}$ & $\begin{array}{c}\text { Chlorophyll } \\
\text { content }\end{array}$ \\
\hline Species (SP) & $<0.001$ & $<0.001$ & $<0.001$ & $<0.001$ & $<0.001$ & $<0.001$ & $<0.001$ & $<0.001$ & $<0.001$ & $<0.001$ \\
\hline Salt (S) & $<0.001$ & $<0.001$ & $<0.001$ & $<0.001$ & $<0.001$ & $<0.095$ & $<0.001$ & $<0.001$ & $<0.001$ & $<0.001$ \\
\hline $\mathrm{SP} \times \mathrm{S}$ & $<0.001$ & $<0.001$ & $<0.001$ & $<0.001$ & $<0.001$ & 0.038 & $<0.001$ & $<0.001$ & $<0.001$ & $<0.001$ \\
\hline
\end{tabular}


Table 4. The effects of foliar salt $(7 \%)$ on chlorophyll fluorescence $\left(\mathrm{F}_{v} / \mathrm{F}_{\mathrm{m}}\right)$, leaf necrosis and chlorophyll content of whole plants. Measurements were made immediately before salt application and values are expressed as the percentage reduction from control values 2 weeks post-treatment when trees were placed under glasshouse conditions $\left(22 \pm 2{ }^{\circ} \mathrm{C}, 16 \mathrm{~h}\right.$ light $/ 8 \mathrm{~h}$ dark photoperiod and minimum 250 $\mu \mathrm{mol} \cdot \mathrm{m}^{-2} \cdot \mathrm{s}^{-1}$ PAR at the tree crown). Species are ranked in order of tolerance based in reductions in percent values of $\mathrm{F}_{\mathrm{v}} / \mathrm{F}_{\mathrm{m}}$ from controls. All values mean of 12 plants, 5 leaves per plant.

\begin{tabular}{lccc}
\hline & $\mathrm{F}_{\mathrm{v}} / \mathrm{F}_{\mathrm{m}}(\%)$ & Leaf necrosis & Chlorophyll content (\%) \\
\hline Brachyglottis dunedin hybrid 'Sunshine' & 1.5 & 5.6 & 5.4 \\
Cotoneaster cashmiriensis & 6.2 & 6.9 & 6.1 \\
Ribes sanguineum & 28.6 & 36.9 & 32.7 \\
Pyrancantha 'Orange Glow' & 30.9 & 35.8 & 37.5 \\
Forsythia $\times$ intermedia & 70.0 & 75.4 & 68.6 \\
Viburnum $\times$ carlcephalum & 71.8 & 77.8 & 69.0 \\
$P$ & $<0.05$ & $<0.05$ & $<0.05$ \\
LSD & 28.27 & 26.34 & 26.10 \\
\hline
\end{tabular}

Leafnecrosis. Assessments of salt damage to leaves were estimated visually on a 1 to 6 scale $(0=$ no necrosis; $1=<1 \%$ necrosis; $2=$ $1 \%$ to $10 \%$ necrosis; $3=11 \%$ to $25 \%$ necrosis; $4=26 \%$ to $50 \%$ necrosis; $5=>51 \%$ to $75 \%$ necrosis; $6=>75 \%$ necrosis). Assessments were made at the same time and on the same leaves
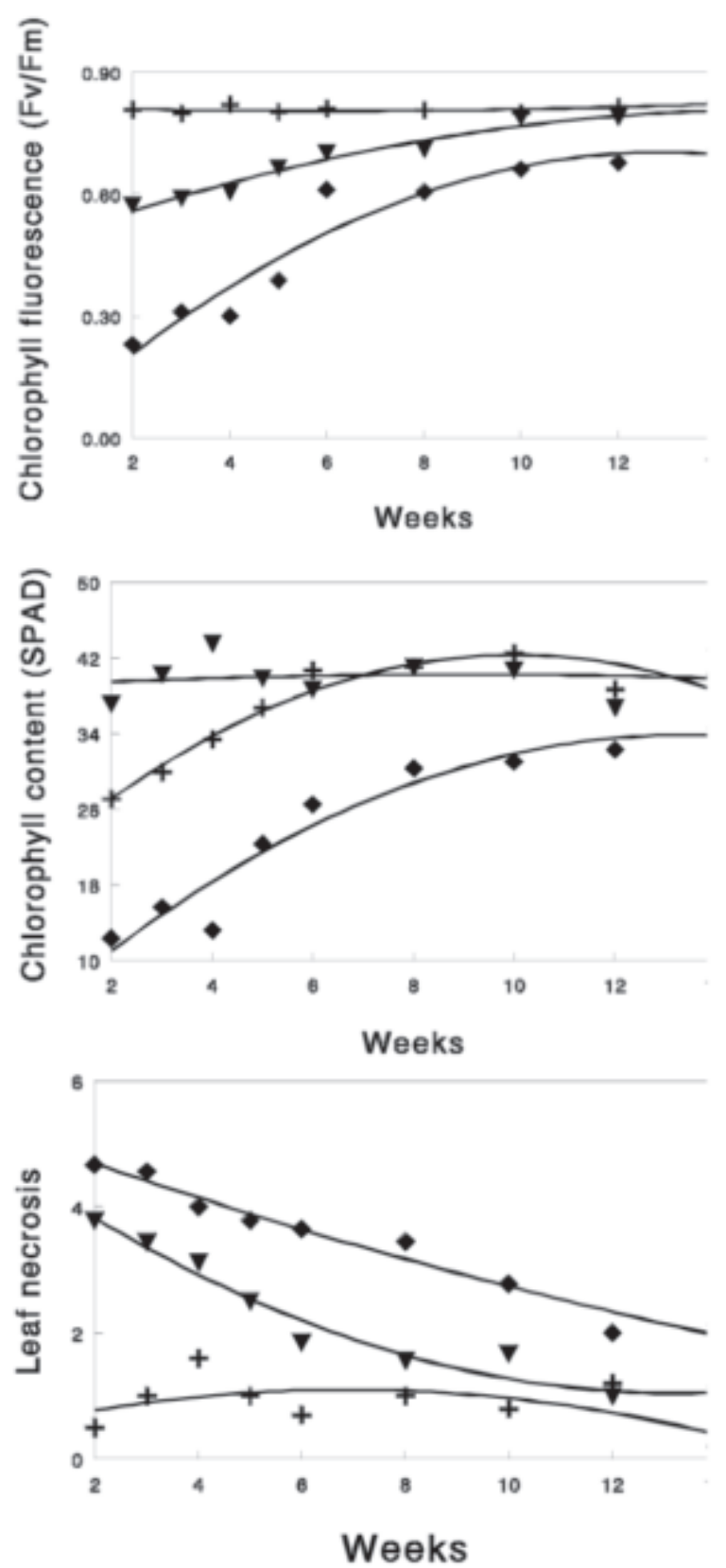

1894 tree. ${ }^{*}$ Species $=$ SP, salt $=S$, interaction $=\mathrm{SP} \times \mathrm{S}$. fluorescence, leaf necrosis and chlorophyll content values of each species, consequently values represent pooled data for both years.

\section{Results}

Excised leaves under laboratory conditions. Values of detached leaves after $72 \mathrm{~h}$ dark storage not subject to salt immersion did not significantly differ from values recorded on whole plants demonstrating no significant effect of leaf detachment on $\mathrm{F} / \mathrm{F}_{\mathrm{m}}$ after $72 \mathrm{~h}$ (Table 1). Likewise no significant intraspecific differences in $\mathrm{F}_{\mathrm{v}} / \mathrm{F}_{\mathrm{m}}$ values between the thirty species selected for experimental purposes were recorded. $F / F_{m}$ values of all species ranged between $0.789-0.834$ (Table 1).

A significant effect of species, salt and species $\times$ salt interaction $(\mathrm{P}>0.05)$, however, was recorded (Table 2). This is reflected by marked differences in the magnitude of the salt damage response (the slope value represented by the letter b) recorded on foliar tissue of the thirty species tested (Table 2 ). $\mathrm{F}_{\mathrm{v}} / \mathrm{F}_{\mathrm{m}}$ regression values ranged from $\mathrm{y}=0.82+0.003 \mathrm{~T}$ for Brachyglottis dunedin hybrids 'Sunshine' indicating this species as possessing the most salt tolerant foliar tissue of the thirty tested, to $\mathrm{y}=0.82-0.056 \mathrm{~T}$ for Viburnum $\times$ carlcephalum indicating this species as the most sensitive tested. Differences in $\mathrm{F} / \mathrm{F}$ regression values between Ribes odoratum, R.sanguineum, Euonymus fortunei 'Emerald \& Gold', E. fortunei 'Silver Queen', Berberis $\times$ carminea 'Buccaneer', Berberis thunbergii 'Aurea', and Berberis thunbergii f. atropurpurea, indicate use of the chlorophyll fluorescence parameter $\mathrm{F}_{\mathrm{v}} / \mathrm{F}_{\mathrm{m}}$ can distinguish marked differences in salt tolerance among species of the same genera. Increasing salinity reduced $\mathrm{F}_{\mathrm{v}} / \mathrm{F}_{\mathrm{m}}$ values of all plants tested with two exceptions, Brachyglottis dunedin hybrids 'Sunshine' and Euonymous fortunei 'Silver Queen', where $\mathrm{F}_{\mathrm{v}} / \mathrm{F}_{\mathrm{m}}$ values were increased. This latter response is associated with improved photosynthetic efficiency in response to excess salinity.

Based on the reductions in $\mathrm{F} / \mathrm{F}_{\mathrm{m}}$ regression values, plants were ranked in decreasing order of tolerance (Table 2). At a salt treatment of $7 \%$, measurements of $F_{v} / F_{m}$ permitted classification of salt tolerance of six of the thirty species tested in the order Brachyglottis dunedin hybrid 'Sunshine'> Cotoneaster cashmiriensis $>$ Ribes sanguineum $>$ Pyrancantha 'Orange Glow' $>$ Forsythia $\times$ intermedia $>$ Viburnum $\times$ carlcephalum, $(0.823,0.795,0.624,0.471$, 0.223 , and 0.133 respectively). Consequently a $7 \%$ foliar salt applications was used as a treatment on whole plants of these six species.

Whole plants: Chlorophyll fluorescence $\left(F_{v} / F_{m}\right)$, leaf necrosis and chlorophyll content (weeks 0 to 2). Two weeks post-salt application $\mathrm{F} / \mathrm{F}$ was reduced to between $1.5 \%$ and $71.8 \%$ of the control pretreatment values depending on species (Table 4$)$. Significant differences $(P$ $<0.05)$ in the reduction of $\mathrm{F}_{\mathrm{v}} / \mathrm{F}_{\mathrm{m}}$ were recorded between species, with Brachyglottis dunedin hybrid 'Sunshine' and Cotoneaster cashmiriensis appearing to be the most resistant to salt induced damage while Forsythia $\times$ intermedia and Viburnum $\times$ carlcephalum identified as the 
most sensitive of the six species tested (Tables 3 and 4). Salt also had a significant effect $(P<$ 0.05 ) on leaf necrosis with values reduced from $5.6 \%$ to $77.8 \%$ of pretreatment controls (Table 4). Reductions in leafnecrosis reflected ranking of species tolerance based on $\mathrm{F}_{\mathrm{v}} / \mathrm{F}_{\mathrm{m}}$ values with again Brachyglottis dunedin hybrid 'Sunshine' and Cotoneaster cashmiriensis identified as the most salt resistant and Forsythia $\times$ intermedia and Viburnum $\times$ carlcephalum the most sensitive. Irrespective of species, leaf chlorophyll content was markedly reduced 2 weeks post salt treatment. The greatest reduction in chlorophyll content was recorded in Forsythia $\times$ intermedia $(69.0 \%)$ and the least reduction was recorded in Brachyglottis dunedin hybrid 'Sunshine' $(5.4 \%)$. Greatest reductions in $\mathrm{F}_{\mathrm{v}} / \mathrm{F}_{\mathrm{m}}$ as in the case of Viburnum $\times$ carlcephalum post salinity were reflected by in general maximal reductions in leaf necrosis and chlorophyll content. Likewise least reductions in $\mathrm{F}_{\mathrm{v}} / \mathrm{F}_{\mathrm{m}}$ as in the case of Brachyglottis dunedin hybrid 'Sunshine' were in general reflected by least reductions in leaf necrosis and chlorophyll content indicating a correlation between changes in $\mathrm{F}_{\mathrm{v}} / \mathrm{F}_{\mathrm{m}}$, leaf necrosis and chlorophyll content for all species tested in response to salinity.

Recovery of whole trees (weeks 2 to 14).
For reasons of clarity the pattern of recovery 2 weeks post-salinity in $\mathrm{F}_{\mathrm{v}} / \mathrm{F}_{\mathrm{m}}$, leaf necrosis and chlorophyll content is shown for Brachyglottis dunedin hybrid 'Sunshine', Ribes sanguineum, and Viburnum $\times$ carlcephalum identified as salt tolerant, intermediate and sensitive respectively (Fig. 1). Irrespective of species when whole plants were returned to glasshouse conditions $\left(22 \pm 2{ }^{\circ} \mathrm{C}\right.$ with a $16 \mathrm{~h}$ light $/ 8 \mathrm{~h}$ dark photoperiod and minimum 250 $\mu \mathrm{mol} \cdot \mathrm{m}^{-2} \cdot \mathrm{s}^{-1} \mathrm{PAR}$ at the tree crown) all three parameters began to recover 2 weeks post-salinity. Consequently the pattern of recovery was quantified by regression analysis to compare the rate of recovery of all species from week 2 until the cessation of the experiment at week 14 (Table 5). Brachyglottis dunedin hybrid 'Sunshine' and Cotoneaster cashmiriensis, which appeared to be the most resilient species to salt damage in terms of $\mathrm{F}_{\mathrm{v}} / \mathrm{F}_{\mathrm{m}}$, leaf necrosis and leaf chlorophyll content were little effected by foliar applied salt as reflected by minimal effects on regression values (Fig. 1, Table 5). Contrary to this Viburnum $\times$ carlcephalum and Forsythia $\times$ intermedia, which appeared to be the most sensitive species to salt damage in terms of $\mathrm{F}_{\mathrm{v}} / \mathrm{F}_{\mathrm{m}}$, leaf necrosis and chlorophyll content were markedly damaged by foliar applied salt as reflected in the recovery patterns (Fig. 1, Table 5). For example $\mathrm{F}_{\mathrm{v}} / \mathrm{F}_{\mathrm{m}}$ measurements of healthy, non-stressed plants are associated with values ranging from 0.78 to 0.85 (Demming and Björkman, 1987). Recovery rates in Viburnum $\times$ carlcephalum by week 14 had risen to about 0.60 (Fig. 1). This indicates regeneration but not full functioning of the leaf photosynthetic apparatus at the cessation of the experiment. In the case of Brachyglottis dunedin hybrid'Sunshine' $\mathrm{F}_{\mathrm{v}} / \mathrm{F}_{\mathrm{m}}$ values remained constant between 0.81 to 0.82 throughout the experimental period following application of foliar salt indicating little or no damage to the leaf photosynthetic system (Fig. 1).

Growth. Foliar application of a $7 \%$ salt solution had no significant effect on plant growth (height, leaf area, leaf size, shoot, root, total plant dry weight, and the root to shoot ratio) of Brachyglottis dunedin hybrids 'Sunshine' and Cotoneaster cashmiriensis at the cessation of the experiment (Table 6). In all remaining species salt application significantly reduced $(P<0.05)$ leaf area, shoot, root, and total plant dry weight. Leaf size was significantly reduced $(P<0.05)$ in Ribes sanguineum, Forsythia $\times$ intermedia and Viburnum $\times$ carlcephalum. No

Table 5. Recovery of chlorophyll fluorescence $\left(\mathrm{F}_{\mathrm{v}} / \mathrm{F}_{\mathrm{m}}\right)$, leaf necrosis and chlorophyll content of whole plants placed under glasshouse conditions $\left(22 \pm 2{ }^{\circ} \mathrm{C}, 16\right.$ $\mathrm{h}$ light $/ 8 \mathrm{~h}$ dark photoperiod and minimum $250 \mu \mathrm{mol} \cdot \mathrm{m}^{-2} \cdot \mathrm{s}^{-1}$ PAR at the tree crown) with time (weeks) based on regression analysis. Species are ranked in order of tolerance based on recovery in slope of the linear regression line for $F_{v} / F_{m}$ (the slope value represented by the letter $b$ ); $y=$ chlorophyll fluorescence value; $\mathrm{a}=$ chlorophyll fluorescence of control value (calculated intercept); $\mathrm{b}=$ decreasing rate of fluorescence with increasing freezing temperature $(\mathrm{T}), \mathrm{c}=$ rate of change of fluorescence. All values mean of 12 plants, 5 leaves per plant.

\begin{tabular}{|c|c|c|c|c|c|c|}
\hline Species & $\begin{array}{l}\mathrm{F}_{\mathrm{v}} / \mathrm{F}_{\mathrm{m}} \\
\text { regression: } y=\mathrm{a}+\mathrm{bT}+\mathrm{cT}^{2}\end{array}$ & $r^{2}$ & $\begin{array}{l}\text { Leaf necrosis } \\
\text { regression: } y=\mathrm{a}+\mathrm{bT}+\mathrm{cT}^{2}\end{array}$ & $r^{2}$ & $\begin{array}{l}\text { Chlorophyll content (SPAD) } \\
\text { regression: } y=\mathrm{a}+\mathrm{bT}+\mathrm{cT}^{2}\end{array}$ & $r^{2}$ \\
\hline Cotoneaster cashmiriensis & $\mathrm{y}=0.74+0.015 \mathrm{~T}-0.001 \mathrm{~T}^{2}$ & 0.83 & $\mathrm{y}=1.33-0.065 \mathrm{~T}+0.003 \mathrm{~T}^{2}$ & 0.52 & $\mathrm{y}=39.7-0.037 \mathrm{~T}+0.011 \mathrm{~T}^{2}$ & 0.42 \\
\hline Ribes sanguineum & $\mathrm{y}=0.48+0.043 \mathrm{~T}-0.001 \mathrm{~T}^{2}$ & 0.99 & $\mathrm{y}=4.91-0.584 \mathrm{~T}+0.022 \mathrm{~T}^{2}$ & 0.98 & $\mathrm{y}=18.6+4.746 \mathrm{~T}-0.237 \mathrm{~T}^{2}$ & 0.97 \\
\hline Forsythia $\times$ intel & $\mathrm{y}=0.07+0.080 \mathrm{~T}-0.001 \mathrm{~T}^{2}$ & 0.99 & $6-0.516 \mathrm{~T}+0.021 \mathrm{~T}^{2}$ & 0.96 & $.0+6.443 \mathrm{~T}-0.272 \mathrm{~T}^{2}$ & 0.94 \\
\hline Viburnum $\times$ carlcephalum & $\mathrm{y}=0.01+0.108 \mathrm{~T}-0.004 \mathrm{~T}^{2}$ & 0.96 & $\mathrm{y}=5.26-0.294 \mathrm{~T}+0.004 \mathrm{~T}^{2}$ & 0.98 & $\mathrm{y}=2.28+4.727 \mathrm{~T}-0.176 \mathrm{~T}^{2}$ & 0.97 \\
\hline
\end{tabular}

Table 6. The influence of salt damage ( $7 \%$ ) on growth of woody plants at week 14 under glasshouse conditions $\left(22 \pm 2{ }^{\circ} \mathrm{C}, 16 \mathrm{~h} \mathrm{light} / 8 \mathrm{~h}\right.$ dark photoperiod and minimum $250 \mu \mathrm{mol} \cdot \mathrm{m}^{-2} \cdot \mathrm{s}^{-1}$ PAR at the tree crown). All values mean of 12 plants.

\begin{tabular}{|c|c|c|c|c|c|c|c|}
\hline Species & $\begin{array}{l}\text { Plant } \\
\text { ht } \\
(\mathrm{cm})\end{array}$ & $\begin{array}{l}\text { Leaf } \\
\text { area } \\
\left(\mathrm{cm}^{2}\right)\end{array}$ & $\begin{array}{l}\text { Leaf } \\
\text { size } \\
\left(\mathrm{cm}^{2}\right)\end{array}$ & $\begin{array}{c}\text { Shoot } \\
\text { and leaf } \\
\text { dry wt (g) }\end{array}$ & $\begin{array}{c}\text { Root } \\
\text { dry wt } \\
\text { (g) }\end{array}$ & $\begin{array}{l}\text { Root to } \\
\text { shoot } \\
\text { ratio }\end{array}$ & $\begin{array}{c}\text { Total } \\
\text { plant } \\
\text { dry wt (g) }\end{array}$ \\
\hline \multicolumn{8}{|c|}{ B. dunedin hybrid 'Sunshine' } \\
\hline LSD & 2.34 & 37.95 & 0.373 & 3.118 & 1.590 & 0.0769 & 3.236 \\
\hline \multicolumn{8}{|c|}{ Cotoneaster cashmiriensis } \\
\hline Control & 32.8 & 453.0 & 1.22 & 12.66 & 10.57 & 0.84 & 23.22 \\
\hline \multicolumn{8}{|c|}{ Ribes sanguineum } \\
\hline Control & 101.6 & 852.0 & 4.58 & 15.43 & 12.76 & 0.83 & 28.19 \\
\hline Salt & $87.0^{*}$ & $747.2^{*}$ & $4.40^{*}$ & $12.50^{*}$ & $10.26^{*}$ & $0.80^{\mathrm{NS}}$ & $22.76^{*}$ \\
\hline LSD & 4.79 & 41.19 & 0.158 & 2.072 & 1.038 & 0.0560 & 3.001 \\
\hline \multicolumn{8}{|c|}{ Pyrancantha 'Orange Glow' } \\
\hline Control & 97.5 & 749.3 & 3.36 & 14.36 & 10.29 & 0.71 & 24.65 \\
\hline Salt & 86.3 & $627.3^{*}$ & $3.12^{\mathrm{NS}}$ & $11.85^{*}$ & $8.46^{*}$ & $0.71^{\mathrm{NS}}$ & $20.31^{*}$ \\
\hline \multicolumn{8}{|c|}{ Viburnum $\times$ carlcephalum } \\
\hline Control & 63.1 & 467.3 & 17.03 & 12.78 & 14.00 & 1.10 & 26.78 \\
\hline Salt & $47.8^{*}$ & $224.9^{*}$ & $13.23^{*}$ & 5.91 & $6.67^{*}$ & 1.13 & $12.58^{*}$ \\
\hline LSD & 5.80 & 60.33 & 1.799 & 3.599 & 3.624 & $0.053^{\mathrm{NS}}$ & 4.439 \\
\hline
\end{tabular}

NS,"Nonsignificant or significant at $=P \leq 0.05$. 
significant effects were recorded on leaf size for Pyrancantha 'Orange Glow'. Irrespective of species no significant effects were recorded on the root to shoot ratio with one exception; Forsythia $\times$ intermedia where values were significantly $(P<0.05)$ increased. In all cases no plant mortalities were recorded at the cessation of the experiment (data not shown).

\section{Discussion}

Subjecting excised leaf material of thirty woody perennials to a range of salinity regimes under laboratory conditions identified Brachyglottis dunedin hybrid 'Sunshine' and Cotoneaster cashmiriensis as relatively salt resilient species and Forsythia $\times$ intermedia and Viburnum $\times$ carlcephalum as the two most sensitive based on reductions in chlorophyll fluorescence $F_{v} / F_{m}$ values. Two weeks post treatment of whole plants subjected to a $7 \%$ foliar salt application and placing under glasshouse conditions, reductions in $\mathrm{F} / \mathrm{F}$, leaf necrosis and chlorophyll content were lowest in Brachyglottis dunedin hybrid 'Sunshine' and Cotoneaster cashmiriensis and highest in Forsythia ×intermedia and Viburnum $\times$ carlcephalum. Likewise recovery rates of these three parameters of whole plants from weeks 2 to 14 were highest in Brachyglottis dunedin hybrid 'Sunshine' and Cotoneaster cashmiriensis while Forsythia $\times$ intermedia and Viburnum $\times$ carlcephalum had the least capacity for recovery. Finally reductions in growth of whole plants at the cessation of the experiment was lowest in Brachyglottis dunedin hybrid 'Sunshine' and Cotoneaster cashmiriensis and highest in Forsythia xintermedia and Viburnum $\times$ carlcephalum. Consequently, the agreement between laboratory and whole plant data under glasshouse conditions suggest the possibility that laboratory testing can be used to provide a helpful indicator of foliar salt tolerant woody perennials with limited whole plant experiments. In support of this conclusion work elsewhere has shown that chlorophyll fluorescence was able to distinguish between degrees of freezing tolerance amongst wild and cultivated Solanum genotypes, quantify their freezing sensitivity and identify the altitude (higher altitudes equates to increased freezing tolerance) at which species originated, when detached leaf tissue was subjected to a $-5{ }^{\circ} \mathrm{C}$ freezing regime under laboratory conditions (Greaves and Wilson, 1987). Similar results were obtained using rice genotypes (Greaves and Wilson, 1987). Likewise in an investigation to evaluate chlorophyll fluorescence as a means of screening woody plant species of known water stress tolerance using detached leaf material it was concluded that chlorophyll fluorescence can provide a rapid screening technique for assessing drought hardiness in trees and shrubs (Percival and Sheriffs, 2002). Further work has concluded that measurement of chlorophyll fluorescence from excised leaves provides a rapid method to prescreen woody plants for low and high temperature and salinity to provide a quantitative assessment with which to rank whole plants on their stress sensitivity (Hakam et al., 2000; Percival and Sheriffs, 2002; Smillie and Hetherington, 1983; Yamada et al., 1996).

Identification of salt tolerant woody perennials may prove of benefit in temperate regions such as the U.K. as plant deaths due to deicing salt $(\mathrm{NaCl})$ application, especially after a heavy frost, are a major problem in urban landscapes (Dobson, 1991). Selection criteria against this problem will become more important as climatic change may increase the unpredictability of weather patterns resulting in progressively later frosts and concomitant higher application of road de-icing salts on a annual basis (Biggs, 1996). Likewise with increased traffic volume and expansion of road networks throughout the U.K., the quantity of salt used for deicing operations has increased correspondingly (Percival and Henderson, 2003).

Based on survival rates post planting, an appreciation of the salinity tolerance of a few woody perennials used in urban landscapes has emerged, however, hard data on species suitability are poorly developed or in many cases nonexistent. The significance of this problem on plant aesthetics and survival are appreciated by professionals involved in woody plant management. Consequently information is available from commercial suppliers regarding the salt hardiness of some woody perennials and their appropriateness for coastal areas. This information is derived primarily on what can be seen, and what has previously grown and established well in situ under saline conditions (Ancient House Press, 1993; Brunel House, 1997). In agreement with their findings Euonymus fortunei cultivars, Rosa rugosa var. alba and Brachyglottis dunedin hybrids are recommended for coastal planting and ranked high in this investigation. However, Sorbus aria, Crataegus monogyna, and Buddleja davidii forms while not recommended for plantings in direct salt spray are suggested as secondary plantings, yet ranked quite low in this investigation. Replacement with more appropriate species such Laburnum anagyroides, Spirea japonica 'Allgold', Hedera helix Hispanica, or Ribes odoratum identified here as more salt tolerant offer a means of reducing plant mortalities in urban environments subject to excess salinity. Consequently, species planted will remain healthier and of greater longevity reducing labour and replacement costs.

A disadvantage of deriving lists from observed performance is that assumptions as to the tolerance of a genera are made based on few species performance. For example the genus Viburnum and Ribes consist of 150 or more species of evergreen, semi-evergreen and deciduous shrubs located in Northern temperate regions, extending to Southeast Asia and South America. Both genera are recommended for coastal plantings (Ancient House Press; Brunel House, 1997). While it is conceivable that other Viburnum species are salt tolerant both Viburnum $\times$ carlcephalum and Viburnum tinus were ranked relatively low in this investigation. Similarly marked differences between salt tolerance ranking of Ribes sangunium and Ribes odoratum were identified. Consequently, coastal plantings using Ribes odoratum would perform better than that of Ribes sangunium. Importantly results indicate that chlorophyll fluorescence not only provides a means to identify salt tolerant and sensitive species but can distinguish salt hardiness within a single genera.

It is important to emphasise that foliar salt tolerance does not necessarily mean tolerance at or around the root zone. Previous experimentation demonstrated A.cordata to be highly tolerant to foliar salt spray (Percival and Dixon, 1997), however, application of low salt concentrations to the root zone resulted in high mortality rates (Percival et al., 1998). Similar phenomena have been recorded with Acer platanoides, classified as salt tolerant (Sucoff, 1975) and salt sensitive (Schiechtl, 1978). Similarly, Thuja occidentalis was reported as tolerant of salt applied to roots but sensitive to foliar salts (Lumis et al., 1976; Sucoff, 1975), and Juglans nigra is reported to be sensitive to salt in the soil but reasonably tolerant of sprays (Leh, 1975). Results should also be interpreted carefully with regard to providing species with an absolute salt tolerance ranking. Many species are propagated from seed and subsequent progeny may possess wide genetic variation. Similarly ecotypic variation within a species may be very broad offering an abundance of largely untapped genetic resource. Ecotypic variation may account for the fact that Sorbus aria is widely regarded as a salt intermediatetolerant tree (Krapenbauer, 1976; Leh, 1973) yet ranked low in this investigation. Where woody perennials are propagated clonally, however, by vegetative means and therefore possess a very narrow genetic base, chlorophyll fluorescence offers a positive means to rank species tolerance.

In conclusion, wide variation in response to salinity indicates considerable potential exists for the use of chlorophyll fluorescence in the selection of foliar salt hardiness in woody perennials. Our results indicate that the chlorophyll fluorescence parameter $\mathrm{F}_{\mathrm{v}} / \mathrm{F}_{\mathrm{m}}$ can be used on excised leaves under laboratory conditions without destroying whole plants. Consequently, further investigations to evaluate the salt tolerance of a wider range of species and genera are in progress.

\section{Literature Cited}

Ancient House Press. 1993. Notcutts Book of Plants. Ancient House Press, Ipswich, Suffolk, U.K.

Biggs, M. 1996. Low temperature acclimation and associated physiological changes in species of Rhododendron. PhD thesis. Univ. Strathclyde/ SAC Auchincruive, Scotland, U.K

Brennan, R.M. and R.A. Jefferies. 1990. The use of chlorophyll fluorescence in assessment of low temperature hardiness in blackcurrant (Ribes nigrum L.), Ann. Appl. Biol. 117:667-672.

Brunel House. 1997. The Hillier Manual of trees and shrubs. David and Charles plc, Brunel House, Newton Abbot, Devon, U.K.

Cannell, M.G.R. and R.I. Smith. 1983. Themal time, chill days and prediction of budburst in Picea sitchensis, J. Appl. Ecol. 20:951-963.

Dobson, M.C. 1991. De-icing salt damage to trees and shrubs. For. Comm. Bul. 101

Greaves, J.A. and J.M. Wilson. 1987. Chlorophyll fluorescence analysis - An aid to plant breeders, Biologist 34:209-214.

Hakam, P., S. Khanizadeh, J.R. DeEll and C. Richer. 2000 Assessing the chilling tolerance in roses 
using chlorophyll fluorescence. HortScience 35(2):184-186.

Harris R.W. 1998. Arboriculture, care of trees, shrubs and vines in thelandscape. Prentice-Hall, Englewood Cliffs, N.J.

Jimenez M.S., A.M. Gonzalez-Rodriguez, D. Morales, M.C.Cid,A.R. Socorro, and M. Caballero. 1997. Evaluation of chlorophyll fluorescence as a tool for salt stress detection in roses. Photosynthetica 33(2):291-301.

Kitao, M., T.T. Lei and T. Koike. 1998. Application of chlorophyll fluorescence to evaluate Mn tolerance of deciduous broad-leaved tree seedlings native to northern Japan. Tree. Physiol. 18:135-140.

Krapenbauer,A. 1976. Street vegetation and de-icing agents. Central For. 93:23-39.

Leh, H.O. 1973. Investigations into the effects of the use of sodium chloride as a de-icing material on Berlins street trees. Nach. Deut. Plant. 25:163-170.

Leh, H.O. 1975. The damage to street trees from salt used for thawing ice. Deut. Baumschule. 27:250-253.

Lichtenthaler, H.K. and A.R. Wellburn. 1983. Determinations of total carotenoids and chlorophylls $\mathrm{a}$ and $\mathrm{b}$ of leaf extracts in different solvents. Biochem. Soc. Trans. 11:591-593.

Lumis, G.P., G. Hofstra, and R. Hall. 1976. Salt damage to roadside plants, J. Arboricult. 1:4-16.

Meinander, O., S. Somersalo, T. Holopainen, and R.J. Strasser. 1996. Scots Pine after exposure to elevated ozone and carbon dioxide probed by reflectance spectra and chlorophyll a fluorescence transients. J. Plant. Physiol. 148:229-236.

Percival, G.C. and G.R. Dixon. 1997. Detection of salt and waterlogging stress in Alnus cordata by measurement of leaf chlorophyll fluorescence. J. Arboricult. 23(5):181-190.

Percival, G.C., M. Biggs, and G.R. Dixon. 1998. The influence of sodium chloride and waterlogging stress on Alnus cordata. J. Arboricult. 24:19-27.

Percival, G.C and G.A. Fraser. 2001. Measurement of the salinity and freezing tolerance of Crataegus genotypes using chlorophyll fluorescence. J. Arboricult. 27(5):233-245.

Percival, G.C and C. Sheriffs. 2002. Identification of drought tolerant woody perennials using chlorophyll fluorescence. J. Arboricult. 28(5):215-224.

Percival, G.C and A. Henderson. 2003. An assess- ment of the freezing tolerance of urban trees using chlorophyll fluorescence. J. Hort. Sci. Biotechnol. 78:254-260.

Percival, G.C and J. Hitchmough. 1995. Tree establishment and performance in a cool growing season arboretum. Arboricult. J. 19(4):357-371.

Schiechtl, H.M. 1978. New conclusions to the question of resistance of woody plants to thawing salts. Gart. Landschaft. 4:240-245.

Smillie, R.M. and S.E. Hetherington. 1983. Stress tolerance and stress-induced injury in crop plants measured by chlorophyll fluorescence in vivo. Plant Physiol. 72:1043-1050.

Sucoff, E. 1975. Effects of de-icing salts on woody plants along Minnesota roads. Minn. Agr. Expt. Sta. Tech. Bul. 303.

West, D.W. 1986. Stress physiology in trees - Salinity. Acta. Hort. 175:322-329

Willits, D.H. and M.M. Peet. 2001. Using chlorophyll fluorescence to model leaf photosynthesis in greenhouse pepper and tomato. Acta. Hort. 507:311-315.

Yamada, M., T. Hidaka, and H. Fukamachi. 1996. Heat tolerance in leaves of tropical fruit crops as measured by chlorophyll fluorescence. Sci. Hort. 67:39-48. 